derived from Mona, or the Isle of Anglesey, and the several parts are distinguished as the Holyhead group, or Lower Monian, the St. David's group and the equivalent of the South-Stack Series, or Middle Monian, and the Bray-Head group, or Upper Monian.

The "Pebidian" represents the St. David's group, and but for its termination, which indicates a system, might be used as an alternative. The "Dimetian and Arvonian" are intrusive granites, or felsitic flows associated with the same group.

The Monian system, though much metamorphosed in its lowest parts, is not considered Archæan, but as a lower sedimentary system than the Cambrian, and hence the lowest system of our ordinary stratified rocks.

\title{
OOREESPONDEINCH.
}

\section{THE CAUSES OF THE GLACIAL AND MILD PERIODS.}

Sir,-There is a theory on the above subject (due to M. Poisson, I believe) which seems to me worthy of more attention than it has recently received from geologists, viz. that the earth with the entire solar system has travelled through hotter and colder regions of space at different periods. Hotter and colder regions of course mean regions in which it received more or less heat from the stars.

Now that the solar system is moving with considerable velocity through space may be regarded as an established fact, and though it may not have materially changed its position among the stars in historical time, it is otherwise with regard to the much longer geological periods. Mr. Maxwell Hall indeed recently computed that the solar system is moving round a distant centre in a period of 13 or 14 millions of years, though his data I think must be regarded as uncertain. Further, every astronomer knows that there are richer and poorer regions among the stars, the passage of the solar system through which would materially affect the amount of stellar heat.

But it may be thought that the total amount of stellar heat is insignificant compared with solar heat. The observations of Pouillet and Herschel however point to an opposite conclusion. The mean temperature of the earth is more than $500^{\circ} \mathrm{F}$. above the absolute zero, of which according to them not more than $300^{\circ} \mathrm{F}$. is due to solar radiation. The remaining $200^{\circ} \mathrm{F}$. must be ascribed to the heat of the stars. An increase or diminution of 10 per cent. in this would raise or lower the mean temperature of the earth by $20^{\circ} \mathrm{F}$., and such an increase confined to the Northern sky would make the North hemisphere $20^{\circ} \mathrm{F}$. botter than the Southern.

I am aware that the results arrived at by Pouillet and Herschel are doubted by many. Further experiments on the same subject by skilled physicists are much to be desired. And should these experiments result in showing that the total amount of stellar heat is insignificant, this fact would not be altogether favourable to the theory of Dr. Croll. If the solar heat is competent to raise the mean temperature of the earth by $500^{\circ} \mathrm{F}$. instead of $300^{\circ} \mathrm{F}$., the 
increase of $\frac{1}{30} \overline{0}$ which takes place at the maximum eccentricity is competent to raise the mean temperature of the earth by nearly $2^{\circ} \mathrm{F}$.; and this increase of heat being maintained for thousands of years could not fail to affect the position of the lines of perpetual snow. Whether there would be an actual increase of $2^{\circ} \mathrm{F}$. in the mean temperature I need not discuss, because as regards the formation and dissipation of snow and ice the essential element appears to be the quantity of heat absorbed in the course of the year.

\section{3, Belvedere Place, Dublin, Feb. 27. \\ W. H. L. MoncK. \\ ON THE CORRELATION OF THE GRÈS DE BELLEU WITH THE LOWER BAGSHOT.}

Sin,-In discussing Prof. Prestwich's new correlation of our Eocenes, I could not help calling attention to the fact that while in his table the position of the Grès du Soissonnais would be below the London Clay, its Flora coincided with that of our Lower Bagshot at Alum Bay, above the London Clay. This apparent anomaly is capable of explanation.

The only comprehensive publication on the Flora of the Paris Basin is by Watelet, and thongh his determinations possess little interest, the illustrations are sufficient in most cases for comparison. The plants represented therein are mainly from Sézanne and Belleu, with a few from other localities. The precise age of the travertins of Sézanne is, in the absence of direct stratigraphical evidence, an unsolved problem, but the aspect of its flora is so ancient that it is difficult not to agree with Saporta, Schimper and others who place it in the Pal-eocene. It is in fact allied rather to the newest Cretaceons floras of Europe than to any Eocene flora, and its nearest representative in our country is the flora of Ardtun in Mull. The few plants from the Grès "intercalés dans les Sables de Bracheux" and from the Lignites are insufficient to tell us anything, but those from the Calcaire Grossier are well-marked Bournemouth species. It is with the vast majority, however, from the Grès de Belleu, that we have to deal, and these we cannot hesitate in correlating with our Lower Bagshot of Alum Bay. The forms common to the two are a Fern, the Palms, all those highly characteristic forms called Comptonia and Dryandra, the large Ficus Bowerbankii and other species of Ficus, Laurus? Salteri, Quercus or Castanea eocenica, a supposed Cinnamomum Larteti, the flower called Porana, leaves of Acer, and bean-pods of Acacia and Casalpinia. The Podocarpus elegans, Marattia Hookeri, and particularly the Aralia primigenia, so characteristic of Alum Bay, are absent, but the two former are equally absent in the corresponding beds so close at hand as Studland. On the other hand, the Belleu beds are far richer in the trinerved leaves known as Daphnogene and Cinnamomum. Such differences are, however, always met with in separate patches of plants, even if on precisely one horizon and near each other, and do not suffice to affect the main fact, that the facies of the floras is as a whole the same, and very different indeed to any flora above or below them. I have had large series of the plants from both 